\title{
Optimization of the Heat Treatment Parameters for Al-Mg-Si Wrought Alloys Using Taguchi Approach
}

\author{
Chin-Hui Shen (Corresponding author) \\ Department of Mechanical Engineering, Army Academy \\ No.750, Longdong Rd., Zhongli City, Taoyuan County 32093, Taiwan \\ E-mail: s0343007@hotmail.com
}

Received: September 7, 2011 Accepted: September 27, 2011 Published: January 1, 2012

doi:10.5539/jmsr.v1n1p78

URL: http://dx.doi.org/10.5539/jmsr.v1n1p78

\begin{abstract}
This paper describes a heat treatment process using Taguchi's robust design method to determine the optimal heat treatment conditions for $\mathrm{Al}-\mathrm{Mg}$-Si wrought alloys, which is an alloy used in automotive body panels. Important factors influencing the optimization criteria include solution temperature, solution time, pre-aging temperature, and pre-aging time. The optimal heat-treatment conditions for both microhardness and paint-bake response of the $\mathrm{Al}-\mathrm{Mg}-\mathrm{Si}$ wrought alloys are a solution temperature of $550^{\circ} \mathrm{C}$, solution time of $30 \mathrm{~min}$, pre-aging temperature of $90^{\circ} \mathrm{C}$, and pre-aging time of $60 \mathrm{~min}$. The optimal conditions for tensile strength are a solution temperature of $530^{\circ} \mathrm{C}$, solution time of $60 \mathrm{~min}$, pre-aging temperature of $90^{\circ} \mathrm{C}$, and pre-aging time of $30 \mathrm{~min}$. Experimental results indicate that solution temperature is the most significant factor for both microhardness and alloy elongation, solution time is the important factor for yield-strength, and pre-aging temperature is the most significant factor for paint-bake response and ultimate tensile strength.
\end{abstract}

Keywords: Pre-aging, Solution treatment, Taguchi method, Bake hardening

\section{Introduction}

Al-Mg-Si alloys constitute the main stream of alloys used in automotive panels, (Sakurai, 2008) because they are heat-treatable and their strength can easily be controlled by heat treatments. Al-Mg-Si wrought alloys have been the material of choice for outer body panels in a number of automobile models, e.g. Audi A8. These alloys have medium to high strength properties, good formability, good corrosion resistance, and weldability.

The Al-Mg-Si alloys may also be adapted so that they exhibit bake hardening, which occurs during the baking step after painting in the automotive manufacturing process. The baking process followed in the EU and USA involves heat treatments at high temperatures of around 180 to $200{ }^{\circ} \mathrm{C}$; in contrast, in Japan, heat treatments at lower temperatures for short periods (e.g., $170{ }^{\circ} \mathrm{C}$ for $20 \mathrm{~min}$ ) are preferred. The alloys for the outer panels are required to undergo hardening under the baking conditions described above; however, conventional $\mathrm{Al}-\mathrm{Mg}-\mathrm{Si}$ alloys are unable to harden sufficiently under such conditions.

Heat treatments, such as solution treatment, quenching process, pre-aging, and retrogression treatment, are widely used to improve the precipitation hardening behavior of Al-Mg-Si alloys. Many studies have investigated (Birol, Y. 2007; El-Danafa, Solimana, \& Almajida, 2009; He, Zhang, \& Cui, 2010) the heat treatment factors affecting precipitation(Edwards, Stiller, \& Dunlop,1994; Sjölander, E. \& Seifeddine, S., 2010). Examples of these factors include solution temperature, solution time, pre-aging temperature, and pre-aging time; they vary with varying conditions.

Zhang, Zheng, and St John (1998) investigated the influence of solution treatment temperature on the tensile properties of $\mathrm{Al}-7 \mathrm{Si}-\mathrm{O}-3 \mathrm{Mg}$ and found that alloy ductility is independent of the solution treatment temperature. Using a higher solution temperature can significantly reduce the solution time required to achieve a specific tensile elongation value.

Bryant (1999) investigated the effects of pre-aging treatments on an AA6111 aluminum auto body sheet. He found that the optimization of the pre-aging treatment was an effective method for modifying the mechanical properties of the alloy under the pre-aging condition; furthermore, it significantly increased the artificial aging kinetics during early aging times of automotive paint bake cycles. 
Pedersen, and Arnberg (2001) examined the effect of solution heat treatment on mechanical properties and microstructures in Al-Si-Mg foundry alloys, they found that the mechanical properties are related to the amount of $\mathrm{Mg}$ and $\mathrm{Si}$ in the alloys. A high strength is obtained after only $60 \mathrm{~min}$ of solution heat treatment, indicating that the solids solution is rapidly saturated on $\mathrm{Mg}$ and $\mathrm{Si}$.

Birol (2005) investigated whether the pre-aging over a wide temperature range $\left(60-200{ }^{\circ} \mathrm{C}\right)$ was effective in improving the bake hardening response of twin-roll cast (TRC) 6016 sheet. The sheet, when processed without any pre-aging, failed to meet the in-service strength requirements with a rather poor bake hardening response.

Moreover, the relation between solution treatment and pre-aging is inadequately characterized and not very well understood. Therefore, this study investigated the use of the Taguchi method to optimize factors related to the heat treatment of Al-Mg-Si wrought alloys. The factors considered were solution temperature, solution time, pre-aging temperature, and pre-aging time; three conditions of each factor were considered.

Taguchi's orthogonal arrays (OA) (Taguchi, 1993; Glen, 1993) are highly fractional orthogonal designs proposed by Dr. Genichi Taguchi, a Japanese industrialist. The Taguchi method is a powerful tool for designing high-quality systems based on orthogonal arrays and analysis of variance (ANOVA) to minimize the number of experiments and to effectively improve product quality (Birol, 2005; Esmaeili, Lloyd, \& Poole, 2003; Ross, 1988).

There are many advantages for using Taguchi method include (Chang, Yang, Ling \& Chou): (1) Designs orthogonal arrays to balance process parameters and minimize test runs. (2) Employs signal-to-noise ( $\mathrm{S} / \mathrm{N}$ ratio) to analyze experiment data, and conclude more information. Taguchi recommends using the $\mathrm{S} / \mathrm{N}$ ratio for determining quality characteristics implemented in engineering design problems. (3) Estimates individual parameter contributions.

\section{Design of Experiments}

\subsection{Taguchi Method}

The current study obtained contributions of individual process factors and optimal factors for microhardness, paint bake response (PBR) and the tensile property in the heat treatment process of Al-Mg-Si wrought alloys; every factor such as solution temperature, solution time, pre-aging temperature, and pre-aging time, has three levels, respectively. The standard experiment layout 3 level OA L9 $\left(3^{4}\right)$ for factors is listed for this case and shown in Table 1 (Ross, 1988). The interaction between the parameters was neglected. Table 2 gives the factors and their levels. Solubilization is conducted at a temperature high enough to put in solution the alloying elements and obtain a supersaturated solid solution (SSSS), which, in the case of Si and $\mathrm{Mg}$, is normally at 510 to $550^{\circ} \mathrm{C}$. This is the typically know as the "solution temperature". In recent times, the forming of various automobile body panel parts often involved the application of various temperature $\left(50{ }^{\circ} \mathrm{C}, 70^{\circ} \mathrm{C}\right.$ and $\left.90{ }^{\circ} \mathrm{C}\right)$ of pre-aging(Sakurai, 2008) which in turn would influence the ageing characteristics of the alloy.

Table 3 gives the details of the experiment design and approach. The factors under consideration, including solution temperature, solution time, pre-aging temperature, and pre-aging time are listed in the first three columns (A, B, C and D) of the OA L9 $\left(3^{4}\right)$. The outputs, micro hardness, PBR and tensile strength values are the samples underwent short-time artificial aging at $170{ }^{\circ} \mathrm{C}$ for $20 \mathrm{~min}$ to imitate paint bake treatment.

\subsection{Analysis of Variance (ANOVA)}

Taguchi method puts emphasis on $\mathrm{S} / \mathrm{N}$ ratio as opposed to simple average of output. It is so because in order to achieve robustness, we must consider standard deviation instead of basing our decisions merely on averages. For higher is better quality characteristic (for making the system response as large as possible), the $\mathrm{S} / \mathrm{N}$ ratio used for this type response is calculated according to Equation (1) (Taguchi and Konishi, 1987):

$$
S / N(d B)=-10 \log \left(\frac{1}{n} \sum_{i=1}^{n} \frac{1}{y_{i}^{2}}\right)
$$

where:

$d B$ the unit of $\mathrm{S} / \mathrm{N}$ ratio (decibel),

$\mathrm{y}_{i}$ the experimental value of the $i$ th quality characteristic,

$n$ the number of tests.

The results of the experiments were evaluated by the analysis of variance (ANOVA) (Roy, 2001). The main objective of the analysis was to determine the influence of each parameter on the variance of the results, regarding the total variance of all the parameters. To calculate the sum of squares on the variance a more useful equation (2) is used. The calculation of ANOVA was made on the basis of the recommendations in (Roy, 2001). 


$$
S S_{T}=\sum_{i=1}^{N} y_{i}^{2}-\frac{T^{2}}{N}
$$

where:

$S S_{T}$ sum of squares,

$\mathrm{y}_{i}$ value of each result,

$T$ the sum of all results,

$N$ the total number of results.

To calculate the effect of an individual parameter on the variance a more useful equation (3) is used:

$$
S S_{A}=\frac{A_{1}^{2}}{N_{A 1}}+\frac{A_{2}^{2}}{N_{A 2}}+\ldots \ldots .+\frac{A_{n}^{2}}{N_{A n}}-\frac{T^{2}}{N}
$$

where:

$A_{l}$ the sum of results (yi) where parameter $A_{l}$ is present,

$N_{A l}$ number of experiments where parameter $A_{I}$ is present.

To calculate contributions of an individual parameter on the variance a more useful equation (4) is used:

$$
P_{A}=\frac{S S_{A}}{S S_{T}}
$$

where:

$P_{A}$ the contributions of factor.

We decomposed the total sum of the squared deviations $\mathrm{SS}_{\mathrm{T}}$ into four sources: sum of squared deviations, $\mathrm{SS}_{\mathrm{A}}$; solution temperature, $\mathrm{SS}_{\mathrm{B}}$; solution time factor and sum of squared deviations, $\mathrm{SS}_{\mathrm{C}}$; and pre-aging temperature and pre-aging time, $\mathrm{SS}_{\mathrm{D}}$. We used the percentage contribution of each heat-treatment parameter to the total sum of squared deviations, SST, to evaluate the importance of a given heat treatment parameter to the performance characteristic being investigated.

\subsection{Confirmation Tests}

Once the optimal level of the control factors has been selected, the final step is to predict and verify the improvement of the quality characteristic using the optimal level of the control factors. However, if the predictive equation is shown to successfully predict the results for different combinations of control factors, then it is evident that the additive equation applies and the interactions of control factors are low. This is the main purpose of the verification experiment.

The predictive $\mathrm{S} / \mathrm{N}$ ratio ( $\eta_{\text {predictive }}$ ) using the optimal level of the control factors can be calculated as equation (5) (Kwak, 2005; Phadke, Kackar, Speeney, \& Grieco, 1983):

$$
\eta_{\text {predictive }}=\eta_{m}+\sum_{i=1}^{n}\left(\bar{\eta}_{i}-\eta_{m}\right)
$$

where:

$\eta_{m}$ the overall average response (or $\mathrm{S} / \mathrm{N}$ ratio) for the entire orthogonal array,

$\bar{\eta}_{i}$ the average $\mathrm{S} / \mathrm{N}$ ratio at the optimal level,

$n$ the number of the main control factors.

\section{Experimental Procedure}

The alloy studied in this work was prepared using industrial aluminum (99.7\%), copper, magnesium and silicon. These raw materials were melted in a resistance crucible oven as per a certain adding order, and then the molten alloy was cast into ingots in a pre-heated mild steel mould at $150^{\circ} \mathrm{C}$. The chemical composition of the $\mathrm{Al}-\mathrm{Mg}-\mathrm{Si}$ alloy was determined through spark emission spectroscopy; the result is given in Table 4. The ingots were subjected to a $14 \mathrm{~h}, 530{ }^{\circ} \mathrm{C}$ homogenizing treatment, and then furnace cooled to room temperature. Then the ingots were hot-rolled to thick sheets of $4 \mathrm{~mm}$ thickness at $490{ }^{\circ} \mathrm{C}$ and cold-rolled to thin sheets of $1 \mathrm{~mm}$ thickness.

The microhardness of the alloy was measured using a digital micro hardness tester made by WILSON, with a load of $200 \mathrm{~g}$ and holding time of $20 \mathrm{sec}$. The ultimate tensile strength (UTS) and yield strength (YS, $0.2 \%$ offset 
strain) of the specimens were using ASTM-B557M-E8 test samples and gauge length $25 \mathrm{~mm}$. The tests were performed at room temperature (RT) under uniaxial tensile loading using a 10 ton testing machine with a tension speed of $2 \mathrm{~mm} / \mathrm{min}$. Microstructure of the polished sample surface were examined using optical microscopy $(\mathrm{OM})$. Samples for OM were etched with Poulton's reagent. The precipitation behavior of the alloy samples were examined with a High resolution transmission electron microscopy observations were carried out using JEOL JEM 3010, operated at $120 \mathrm{kV}$.

\section{Results and Discussion}

\subsection{Effect of heat treatment on microhardness, PBR, and tensile strength}

Table 5 lists the results of various trial runs under three conditions each of solution temperature, solution time, pre-aging temperature, and pre-aging time. Experiments conducted to maximize microhardness and PBR revealed that the optimal conditions for maximizing the $\mathrm{S} / \mathrm{N}$ ratio were a solution temperature of $550{ }^{\circ} \mathrm{C}\left(\mathrm{A}_{3}\right)$, solution time of $30 \mathrm{~min}\left(\mathrm{~B}_{2}\right)$, pre-aging temperature of $90{ }^{\circ} \mathrm{C}\left(\mathrm{C}_{3}\right)$, and pre-aging time of $60 \mathrm{~min}\left(\mathrm{D}_{3}\right)$, as shown in Figures 1(a) and 1(b). The results indicate that both the microhardness and the PBR of the Al-Mg-Si wrought alloys increase with the solution temperature, pre-aging temperature, and pre-aging time. However, the overall heat treatment process is not a single-stage process involving pre-aging coupled with solution temperature and solution time. During solution treatment, a process called recrystallization causes deformed grains of the $\mathrm{Al}-\mathrm{Mg}-\mathrm{Si}$ wrought alloys to be replaced by a new set of undeformed grains that nucleate and grow until the original grains have been entirely consumed. Thus, this recrystallization process is usually accompanied by a reduction in the hardness of a material.

The S/N ratios were also calculated using the information listed in Table 5. Figures 1(c) and 1(d) show the averaged effects of the various conditions on UTS and YS, respectively. Experiments conducted to maximize UTS and YS revealed that the optimal conditions for maximizing the $\mathrm{S} / \mathrm{N}$ ratio were a solution temperature of $530{ }^{\circ} \mathrm{C}\left(\mathrm{A}_{2}\right)$, solution time of $60 \mathrm{~min}\left(\mathrm{~B}_{3}\right)$, pre-aging temperature of $90{ }^{\circ} \mathrm{C}\left(\mathrm{C}_{3}\right)$, and pre-aging time of $30 \mathrm{~min}$ $\left(\mathrm{D}_{2}\right)$. The results indicate that both the UTS and the YS of the Al-Mg-Si wrought alloys increase with the solution time and pre-aging temperature.

Al-Mg-Si wrought alloys intended for use as body panels are shipped while they still formable as T4 temper, and they are subsequently subjected to a bake cycle to increase their strength. Experiments conducted to maximize $\% \mathrm{El}$ after heat treatment but before paint baking revealed that the optimal conditions for maximizing the $\mathrm{S} / \mathrm{N}$ ratio were a solution temperature of $530{ }^{\circ} \mathrm{C}\left(\mathrm{A}_{2}\right)$, solution time of $60 \mathrm{~min}\left(\mathrm{~B}_{3}\right)$, pre-aging temperature of $50{ }^{\circ} \mathrm{C}$ $\left(\mathrm{C}_{1}\right)$, and pre-aging time of $30 \mathrm{~min}\left(\mathrm{D}_{2}\right)$, as shown in Figure 1(e).

\subsection{Analysis of variance (ANOVA)}

We used the percentage contribution of each heat treatment parameter to the total sum of the squared deviations (SST) to evaluate the importance of a given heat treatment parameter in the performance characteristic being investigated.

As mentioned above, the optimal heat treatment conditions for microhardness and PBR are $A_{3}, B_{2}, C_{3}$, and $D_{3}$. Tables 6 and 7 list the results of ANOVA for microhardness and PBR, respectively. The contributions of solution temperature, solution time, pre-aging temperature, and pre-aging time for microhardness and PBR are $50.79 \%, 5.39 \%, 19.39 \%$, and $24.42 \%$ and $8.99 \%, 7.20 \%, 50.99 \%$, and $32.83 \%$, respectively. The most significant factors affecting microhardness and PBR are solution temperature and pre-aging temperature, respectively.

As mentioned above, the optimal heat treatment conditions for UTS and YS are $\mathrm{A}_{2}, \mathrm{~B}_{3}, \mathrm{C}_{3}$, and $\mathrm{D}_{2}$. The most significant factors affecting UTS and YS are pre-aging temperature and solution time, respectively, as indicated by the ANOVA results listed in Tables 8 and 9 .

As mentioned above, the optimal heat treatment conditions for $\% \mathrm{El}$ are $\mathrm{A}_{2}, \mathrm{~B}_{3}, \mathrm{C}_{1}$, and $\mathrm{D}_{2}$. The most significant factor affecting $\% \mathrm{El}$ before paint baking is solution temperature, as indicated by the ANOVA results listed in Table 10.

\subsection{Verification test results}

After optimizing the process parameters, we carried out a verification test three times to determine the accuracy of the analysis. Table 11 presents comparisons of the predicted microhardness value $(120.3 \mathrm{Hv})$ with the actual microhardness value $(119.5 \mathrm{Hv})$ obtained by averaging the three measurements after heat treatment under optimal conditions. The results obtained by the Taguchi method closely match the ANOVA results, and the predicted and measured values also agree well. 
The results in Tables 11 and 12 indicate that with heat treatment under optimal conditions, the microhardness and PBR increase by approximately $36.3 \mathrm{Hv}$ and $36.8 \mathrm{Hv}$, respectively, relative to the initial condition (without heat treatment). Further, the results in Tables 13 and 14 indicate that UTS and YS increase only slightly by approximately $13 \mathrm{MPa}$ and $6 \mathrm{MPa}$, respectively, relative to the initial condition. The results in Table 15 indicate that $\% \mathrm{El}$ increases significantly by approximately $26.9 \%$; this implies that the formability of these alloys is very good after heat treatment without paint baking. To verify this hypothesis, we examined the microstructures of the samples.

Figure 2 shows the microstructure of the Al-Mg-Si wrought alloys before heat treatment. The micrograph clearly shows a dense and elongated grain structure oriented along the cold rolling direction. Plastic deformation causes (1) change in grain size, (2) strain hardening (Anderson and Mehl, 1945), (3) increase in dislocation density, and (4) decrease in ductility; \% El of the Al-Mg-Si wrought alloys decreased to $7.27 \%$, making the sample unsuitable for cold working.

Figure 3 shows the microstructure of the Al-Mg-Si wrought alloys after heat treatment under $\mathrm{A}_{2} \mathrm{~B}_{3} \mathrm{C}_{1} \mathrm{D}_{2}$ conditions. The crystal grain was completely recrystallized and \%El increased to $34.17 \%$, satisfying the requirements of an aluminum body panel with T4 temper (Kleiner, Henkel, Schulz, \& Uggowitzer, 2001; Miller, Zhuang, Bottema, Wittebrood, Smet, Haszler, \& Vieregge, 2000).

Figure 4 shows high-resolution transmission electron microscopy (HR-TEM) micrographs of an $\mathrm{Al}-\mathrm{Mg}-\mathrm{Si}$ wrought alloy sample after heat treatment under $\mathrm{A}_{2} \mathrm{~B}_{3} \mathrm{C}_{3} \mathrm{D}_{2}$ conditions followed by paint baking at $170{ }^{\circ} \mathrm{C}$ for 20 min. The presence of $\beta^{\prime \prime}$ precipitates causes a strengthening effect (Edwards, Stiller, \& Dunlop, 1994); consequently, microhardness increases significantly. However, the precipitate size is limited because paint baking was carried out for only $20 \mathrm{~min}$, and UTS and YS increased only slightly, by approximately $13 \mathrm{MPa}$ and $6 \mathrm{MPa}$, respectively.

\section{Conclusions}

We applied Taguchi's robust design method to determine the optimal heat treatment conditions for the Al-Mg-Si wrought alloy. The following conclusions were drawn from the experimental results:

1) The optimal heat treatment conditions for maximizing the microhardness and PBR of the Al-Mg-Si wrought alloy are a solution temperature of $550{ }^{\circ} \mathrm{C}$, solution time of $30 \mathrm{~min}$, pre-aging temperature of $90{ }^{\circ} \mathrm{C}$, and pre-aging time of $60 \mathrm{~min}$. With heat treatment under these optimal conditions, the microhardness and PBR increased by approximately $36.3 \mathrm{Hv}$ and $36.8 \mathrm{Hv}$, respectively, relative to the initial condition.

2) The optimal heat treatment conditions for maximizing the UTS and YS of the Al-Mg-Si wrought alloy are a solution temperature of $530{ }^{\circ} \mathrm{C}$, solution time of $60 \mathrm{~min}$, pre-aging temperature of $90{ }^{\circ} \mathrm{C}$, and pre-aging time of $30 \mathrm{~min}$.

3) The optimal heat treatment conditions for maximizing the $\% \mathrm{El}$ of the Al-Mg-Si wrought alloy are a solution temperature of $530{ }^{\circ} \mathrm{C}$, solution time of $60 \mathrm{~min}$, pre-aging temperature of $50{ }^{\circ} \mathrm{C}$, and pre-aging time of $30 \mathrm{~min}$. Before paint baking, $\% \mathrm{El}$ increased by approximately $26.9 \%$ relative to the initial condition.

4) In a decreasing order of importance, the factors affecting microhardness of Al-Mg-Si wrought alloys are as follows: solution temperature, pre-aging time, pre-aging temperature, and solution time. The microhardness of the alloys increases with the solution temperature, pre-aging temperature, and pre-aging time.

5) In a decreasing order of importance, the factors affecting PBR and UTS are as follows: pre-aging temperature, pre-aging time, solution temperature, and solution time. The PBR increases with solution temperature, pre-aging temperature, and pre-aging time. Because paint baking was carried out for only 20 min, PBR increased only slightly relative to the initial condition.

6) In a decreasing order of importance, the factors affecting \%El are as follows: solution temperature, pre-aging temperature, solution time, and pre-aging time. After heat treatment, the Al-Mg-Si wrought alloys have high formability; this allows for stamping of complex shapes with a high accuracy in the T4 temper.

\section{References}

Arnberg, L., \& Pedersen, L. (2001). The Effect of Solution Heat Treatment and Quenching Rates on Mechanical Properties and Microstructures in Al-Si-Mg foundry alloys. Metallurgical and Materials Transactions, 32A(3), 525-532. http://dx.doi.org/10.1007/s11661-001-0069-y

Anderson, W. A., \& Mehl, R. F. (1945). Recrystal of Aluminum in Terms of the Rate of Nnucleation and the Rate of Growth. Ameri an Institute of Mining Engineering Transactions, 161, 140-172. 
Birol, Y. (2005). Pre-Ageing to Improve Bake Hardening in a Twin-roll Cast Al-Mg-Si Alloy. Materials Science and Engineering A, 391, 175-180. http://dx.doi.org/10.1016/j.msea.2004.08.069

Birol, Y. (2007). Reversion Treatment to Improve Bake Hardening Response of a Twin-Roll Cast 6016 Automotive Sheet. Materials Science Forum, 539-543, 345-350. http://dx.doi.org/10.4028/www.scientific.net/MSF.539-543.345

Bryant, D. (1999). The Effects of Pre-aging Treatments on Aging Kinetics and Mechanical Properties in AA6111 Aluminum Autobody Sheet. Metallurgical and Materials Transactions A, 30A, 1999-2006. http://dx.doi.org/10.1007/s11661-999-0010-3

Chang, C. C., Yang, J. G., Ling C., \& Chou, C. P. (2010). Optimization of Heat Treatment Parameters with the Taguchi Method for the A7050 Aluminum Alloy. IACSIT International Journal of Engineering and Technology, 2(3), 269-272.

Edwards, G. A., Stiller, K., \& Dunlop, G. L. (1994). APFIM Investigation of Fine-Scale Precipitation in Aluminium Alloy 6061. Applied Surface Science, 76-77, 219-225. http://dx.doi.org/10.1016/0169-4332(94)90346-8

El-Danafa, E. A., Solimana M. S. and Almajida, A. A. (2009). Effect of Solution Heat Treatment on the Hot Workability of Al-Mg-Si Alloy. Materials and Manufacturing Processes, 24(6), 637-643. http://dx.doi.org/10.1080/10426910902769079

Esmaeili, S., Lloyd, D. J., \& Poole, W. J. (2003). Modeling of Precipitation Hardening for the Naturally Aged Al-Mg-Si-Cu Alloy AA6111. Acta Materialia, 51, 3467-3481. http://dx.doi.org/10.1016/S1359-6454(03)00167-8

He, L. , Zhang, H. T., \& Cui, J. Z. (2010). Effects of Pre-Ageing Treatment on Subsequent Artificial Ageing Characteristics of an Al-1.01Mg-0.68Si-1.78Cu Alloy. J. Mater. Sci. Technol., 26(2), 141-145. http://dx.doi.org/10.1016/S1005-0302(10)60023-0

Kleiner, S., Henkel, Ch., Schulz, P., \& Uggowitzer, P. J. (2001). Paint Bake Response of Aluminium Alloy 6016. Aluminium. 77, 185-189. http://dx.doi.org/10.1023/A:1009800310840

Kwak, J. S. (2005). Application of Taguchi and Response Surface Methodologies for Geometric Error in Surface Grinding Process. International Journal of Machine Tools \& Manufacture. 45, 327-334. http://dx.doi.org/10.1016/j.ijmachtools.2004.08.007

Miller, W. S., Zhuang, L., Bottema, J., Wittebrood, A. J., Smet, P. De, Haszler, A., \& Vieregge, A. (2000). Recent Development in Aluminum Alloys for the Automotive Industry. Materials Science and Engineering A, 280, 37-49. http://dx.doi.org/10.1016/S0921-5093(99)00653-X

Glen, S. P. (1993). Taguchi Methods: A Hands-on Approach to Quality Engineering, (273-311). New York, NY: Addison-Wesley.

Phadke, M. S., Kackar, R. N., Speeney, D. D., \& Grieco, M. J. (1983). Off-line Quality Control in Integrated Circuit Fabrication Using Experimental Design. The Bell System Technical Journal. 62(5), 1273-1309.

Ross, P. J. (1988). Taguchi Techniques for Quality Engineering: loss function, orthogonal experiments, parameter and tolerance design. New York, NY: McGraw-Hill.

Roy, R. K. (2001). Design of Experiments Using the Taguchi Approach: 16 Steps to Product and Process Improvement. New York, NY: John Willey \& Sons, Inc.

Sakurai, T. (2008). The Latest Trends in Aluminum Alloy Sheets for Automotive Body Panels. Kobelco Technology Review, 28, 22-28.

Sjölander, E., \& Seifeddine, S. (2010). The Heat Treatment of Al-Si-Cu-Mg Casting Alloys. Journal of Materials Processing Technology, 210(10), 1249-1259. http://dx.doi.org/10.1016/j.jmatprotec.2010.03.020

Taguchi, G. (1993). Taguchi on Robust Technology Development: Bringing Quality Engineering Upstream. New York, NY: ASME Press. http://dx.doi.org/10.1115/1.800288

Taguchi, G., \& Konishi, S. (1987). Taguchi Methods Orthogonal Arrays and Linear Graphs: Tools for Quality Engineering. USA: American Supplier Institute, Dearborn, MI.

Zhang, D. L. ,Zheng, L. H., \& StJohn, D. H. (1998). Effect of Solution Treatment Temperature on Tensile Properties of Al-7Si-O-3Mg Alloy. Materials Science and Technology, 14(7), 619-625. 
Table 1. Experimental layout using L9 $\left(3^{4}\right)$ orthogonal arrays

\begin{tabular}{cccccc}
\hline \multirow{2}{*}{$\begin{array}{c}\text { Trial } \\
\text { No. }\end{array}$} & \multicolumn{4}{c}{ Heat treatment parameters } & \multirow{2}{*}{ Test } \\
\cline { 2 - 4 } result \\
\hline 1 & A & B & C & D & \\
2 & 1 & 1 & 1 & 1 & \\
3 & 1 & 2 & 2 & 2 & \\
4 & 2 & 3 & 3 & 3 & \\
5 & 2 & 2 & 2 & 3 & \\
6 & 2 & 3 & 1 & 1 & \\
7 & 3 & 1 & 3 & 2 & \\
8 & 3 & 2 & 1 & 3 & \\
9 & 3 & 3 & 2 & 1 & \\
\hline
\end{tabular}

Table 2. Heat-treatment conditions and their values

\begin{tabular}{ccccc}
\hline & \multicolumn{3}{c}{ Heat treatment parameters } \\
\cline { 2 - 5 } Level & \multicolumn{2}{c}{ Solution } & \multicolumn{2}{c}{ Pre-aging } \\
\cline { 2 - 5 } & $\begin{array}{c}\text { A:temp. B:time C:temp. D:time } \\
\left({ }^{\circ} \mathrm{C}\right)\end{array}$ & $(\mathrm{min})$ & $\left({ }^{\circ} \mathrm{C}\right)$ & $(\mathrm{min})$ \\
\hline 1 & 510 & 10 & 50 & 1 \\
2 & 530 & 30 & 70 & 30 \\
3 & 550 & 60 & 90 & 60 \\
\hline
\end{tabular}

Table 3. Experimental design and results for each heat-treatment process

\begin{tabular}{|c|c|c|c|c|c|c|c|c|}
\hline \multirow{2}{*}{$\begin{array}{l}\text { Trial } \\
\text { No. }\end{array}$} & \multicolumn{4}{|c|}{$\begin{array}{c}\text { Heat treatment } \\
\text { parameters }\end{array}$} & \multirow{2}{*}{$\begin{array}{c}\text { micro } \\
\text { hardness }\end{array}$} & \multirow{2}{*}{$\begin{array}{c}\text { paint ultimate } \\
\text { bake tensile } \\
\text { response strength }\end{array}$} & \multirow{2}{*}{$\begin{array}{c}\text { yield } \\
\text { strength }\end{array}$} & \multirow{2}{*}{ elongation } \\
\hline & A & B & $\mathrm{C}$ & $\mathrm{D}$ & & & & \\
\hline 1 & 510 & 10 & 50 & 1 & & & & \\
\hline 2 & 510 & 30 & 70 & 30 & & & & \\
\hline 3 & 510 & 60 & 90 & 60 & & & & \\
\hline 4 & 530 & 10 & 70 & 60 & & & & \\
\hline 5 & 530 & 30 & 90 & 1 & & & & \\
\hline 6 & 530 & 60 & 50 & 30 & & & & \\
\hline 7 & 550 & 10 & 90 & 30 & & & & \\
\hline 8 & 550 & 30 & 50 & 60 & & & & \\
\hline 9 & 550 & 60 & 70 & 1 & & & & \\
\hline
\end{tabular}

Table 4. Chemical composition of Al-Mg-Si alloy (wt\%)

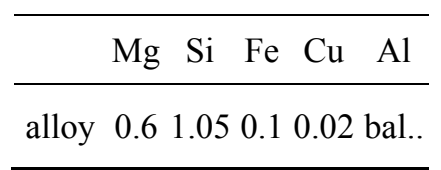


Table 5. Experimental design and results for each heat-treatment process

\begin{tabular}{|c|c|c|c|c|c|c|c|c|c|c|c|c|c|}
\hline \multirow[t]{2}{*}{$\begin{array}{l}\text { Trial } \\
\text { No. }\end{array}$} & \multicolumn{3}{|c|}{$\begin{array}{c}\text { Heat } \\
\text { treatment } \\
\text { parameters }\end{array}$} & \multirow[t]{2}{*}{$\mathrm{Hv}_{1}$} & \multirow[t]{2}{*}{$\mathrm{Hv}_{2}$} & \multirow[t]{2}{*}{$\mathrm{Hv}_{2}{ }^{*}$} & \multirow[t]{2}{*}{$\triangle \mathrm{Hv}$} & \multirow[t]{2}{*}{$\triangle \mathrm{Hv}^{*}$} & \multirow[t]{2}{*}{ UTS L } & \multirow[t]{2}{*}{ YS } & \multirow{2}{*}{\multicolumn{2}{|c|}{$\mathrm{YS}^{*}$}} & \multirow[t]{2}{*}{$\% \mathrm{El}^{*}$} \\
\hline & A B & $\mathrm{C}$ & & & & & & & & & & & \\
\hline 1 & 51010 & 50 & 1 & 81.0 & 85.0 & 38.59 & 4.0 & 12.0 & 226.547 .09 & 89.67 & 38.99 & $31.58 \%$ & 29.99 \\
\hline 2 & 51030 & 70 & 30 & 85.4 & 97.2 & 39.75 & 11.8 & 21.4 & 254.048 .10 & 102.67 & 40.21 & $30.51 \%$ & 29.69 \\
\hline 3 & 51060 & 90 & 60 & 81.4 & 104.0 & 40.34 & 22.6 & 27.1 & 279.748 .93 & 102.67 & 40.22 & $31.78 \%$ & 30.04 \\
\hline 4 & 53010 & 70 & 60 & 88.2 & 101.9 & 40.16 & 13.7 & 22.7 & 262.948 .40 & 97.33 & 39.76 & $32.37 \%$ & 30.20 \\
\hline 5 & 53030 & 90 & 1 & 87.7 & 103.8 & 40.32 & 16.1 & 24.1 & 265.448 .48 & 101.67 & 40.14 & $33.02 \%$ & 30.38 \\
\hline 6 & 53060 & 50 & 30 & 90.8 & 102.4 & 40.21 & 11.6 & 21.3 & 272.148 .70 & 105.67 & 40.48 & $34.53 \%$ & 30.76 \\
\hline 7 & 55010 & 90 & 30 & 93.3 & 113.9 & 41.13 & 20.6 & 26.3 & 282.149 .01 & 101.67 & 40.14 & $33.32 \%$ & 30.45 \\
\hline 8 & 55030 & 50 & 60 & 97.5 & 111.1 & 40.91 & 13.6 & 22.7 & 255.448 .15 & 97.33 & 39.73 & $33.34 \%$ & 30.46 \\
\hline 9 & 55060 & 70 & 1 & 92.7 & 102.4 & 40.20 & 9.7 & 19.7 & 260.948 .33 & 101.67 & 40.14 & $32.96 \%$ & 30.36 \\
\hline
\end{tabular}

$\mathrm{Hv}_{1}$ : micro hardness after heat treatment

$\mathrm{Hv}_{2}$ : micro hardness after paint bake treatment

$\mathrm{Hv}_{2}{ }^{*}: \mathrm{S} / \mathrm{N}$ ratio for $\mathrm{Hv}_{2}$

$\triangle \mathrm{Hv}=\mathrm{Hv}_{2}-\mathrm{Hv}_{1}$ (PBR)

$\triangle \mathrm{Hv}^{*}: \mathrm{S} / \mathrm{N}$ ratio for $\triangle \mathrm{Hv}$
UTS: ultimate tensile strength

$\mathrm{UTS}^{*}: \mathrm{S} / \mathrm{N}$ ratio for UTS

YS: yield strength

$\mathrm{YS}^{*}: \mathrm{S} / \mathrm{N}$ ratio for $\mathrm{YS}$

$\%$ El: elongation after heat treatment

$\% \mathrm{El}^{*}: \mathrm{S} / \mathrm{N}$ ratio for $\% \mathrm{El}$

Table 6. Results of analysis of variance for microhardness

\begin{tabular}{cccr}
\hline \multirow{2}{*}{ symbol } & $\begin{array}{c}\text { Heat treatment } \\
\text { parameter }\end{array}$ & Sum of Squares & Contribution \\
\hline $\mathrm{SS}_{\mathrm{A}}$ & Solution temp. & 2.13 & $50.79 \%$ \\
$\mathrm{SS}_{\mathrm{B}}$ & Solution time & 0.23 & $5.39 \%$ \\
$\mathrm{SS}_{\mathrm{C}}$ & Pre-aging temp. & 0.81 & $19.39 \%$ \\
$\mathrm{SS}_{\mathrm{D}}$ & Pre-aging time & 1.03 & $24.42 \%$ \\
$\mathrm{SS}_{\mathrm{T}}$ & & 4.20 & \\
\hline
\end{tabular}

Table 7. Results of analysis of variance for PBR

\begin{tabular}{cccc}
\hline symbol & $\begin{array}{c}\text { Heat treatment } \\
\text { parameter }\end{array}$ & Sum of Squares & Contribution \\
\hline $\mathrm{SS}_{\mathrm{A}}$ & Solution temp. & 13.90 & $8.99 \%$ \\
$\mathrm{SS}_{\mathrm{B}}$ & Solution time & 11.13 & $7.20 \%$ \\
$\mathrm{SS}_{\mathrm{C}}$ & Pre-aging temp. & 78.87 & $50.99 \%$ \\
$\mathrm{SS}_{\mathrm{D}}$ & Pre-aging time & 50.77 & $32.83 \%$ \\
$\mathrm{SS}_{\mathrm{T}}$ & & 154.67 & \\
\hline
\end{tabular}


Table 8. Results of analysis of variance for UTS

\begin{tabular}{cccc}
\hline symbol & $\begin{array}{c}\text { Heat treatment } \\
\text { parameter }\end{array}$ & Sum of Squares & Contribution \\
\hline $\mathrm{SS}_{\mathrm{A}}$ & Solution temp. & 0.443 & $16.92 \%$ \\
$\mathrm{SS}_{\mathrm{B}}$ & Solution time & 0.416 & $15.89 \%$ \\
$\mathrm{SS}_{\mathrm{C}}$ & Pre-aging temp. & 1.061 & $40.56 \%$ \\
$\mathrm{SS}_{\mathrm{D}}$ & Pre-aging time & 0.697 & $26.63 \%$ \\
$\mathrm{SS}_{\mathrm{T}}$ & & 2.616 & \\
\hline
\end{tabular}

Table 9. Results of analysis of variance for YS

\begin{tabular}{lccc}
\hline symbol & $\begin{array}{c}\text { Heat treatment } \\
\text { parameter }\end{array}$ & Sum of Squares & Contribution \\
\hline $\mathrm{SS}_{\mathrm{A}}$ & Solution temp. & 0.152 & $9.96 \%$ \\
$\mathrm{SS}_{\mathrm{B}}$ & Solution time & 0.644 & $42.21 \%$ \\
$\mathrm{SS}_{\mathrm{C}}$ & Pre-aging temp. & 0.298 & $19.53 \%$ \\
$\mathrm{SS}_{\mathrm{D}}$ & Pre-aging time & 0.432 & $28.29 \%$ \\
$\mathrm{SS}_{\mathrm{T}}$ & & 1.526 & \\
\hline
\end{tabular}

Table 10. Results of analysis of variance for $\% \mathrm{El}$

\begin{tabular}{cccc}
\hline symbol & $\begin{array}{c}\text { Heat treatment } \\
\text { parameter }\end{array}$ & Sum of Squares & Contribution \\
\hline $\mathrm{SS}_{\mathrm{A}}$ & Solution temp. & 0.56 & $69.65 \%$ \\
$\mathrm{SS}_{\mathrm{B}}$ & Solution time & 0.08 & $9.58 \%$ \\
$\mathrm{SS}_{\mathrm{C}}$ & Pre-aging temp. & 0.16 & $19.72 \%$ \\
$\mathrm{SS}_{\mathrm{D}}$ & Pre-aging time & 0.01 & $1.05 \%$ \\
$\mathrm{SS}_{\mathrm{T}}$ & & 0.81 & \\
\hline
\end{tabular}

Table 11. Verification test results for optimal heat-treatment conditions for microhardness

\begin{tabular}{llcc}
\hline Conditions & Level & $\begin{array}{c}\text { hardness } \\
(\mathrm{Hv})\end{array}$ & $\begin{array}{l}\text { S/N Ratio } \\
(\mathrm{dB})\end{array}$ \\
\hline Prediction & $\mathrm{A}_{3} \mathrm{~B}_{2} \mathrm{C}_{3} \mathrm{D}_{3}$ & 120.3 & 41.61 \\
Measurement & $\mathrm{A}_{3} \mathrm{~B}_{2} \mathrm{C}_{3} \mathrm{D}_{3}$ & 119.5 & 41.55 \\
Initial & No Heat & 83.2 & 38.40 \\
& Treatment & & \\
Improvement & & 36.3 & 3.15 \\
\hline
\end{tabular}


Table 12. Verification test results for optimal heat-treatment conditions for PBR

\begin{tabular}{|c|c|c|c|}
\hline Conditions & Level & $\begin{array}{l}\text { PBR } \\
(\mathrm{Hv})\end{array}$ & $\begin{array}{l}\text { S/N Ratio } \\
\text { (dB) }\end{array}$ \\
\hline Prediction & $\mathrm{A}_{3} \mathrm{~B}_{2} \mathrm{C}_{3} \mathrm{D}_{3}$ & +31.0 & 29.83 \\
\hline Measurement & $\mathrm{A}_{3} \mathrm{~B}_{2} \mathrm{C}_{3} \mathrm{D}_{3}$ & +31.8 & 30.04 \\
\hline Initial & $\begin{array}{l}\text { No Heat } \\
\text { Treatment }\end{array}$ & -5.0 & 13.98 \\
\hline Improvement & $(+): \mathrm{i}$ & $\begin{array}{l}+36.8 \\
\text { crease }(\end{array}$ & $\begin{array}{c}31.32 \\
: \text { decrease }\end{array}$ \\
\hline
\end{tabular}

Table 13. Verification test results for optimal heat-treatment conditions for UTS

\begin{tabular}{llcc}
\hline Conditions & Level & $\begin{array}{l}\text { UTS } \\
(\mathrm{MPa})\end{array}$ & $\begin{array}{l}\mathrm{S} / \mathrm{N} \text { Ratio } \\
(\mathrm{dB})\end{array}$ \\
\hline Prediction & $\mathrm{A}_{2} \mathrm{~B}_{3} \mathrm{C}_{3} \mathrm{D}_{2}$ & 299.5 & 49.53 \\
Measurement & $\mathrm{A}_{2} \mathrm{~B}_{3} \mathrm{C}_{3} \mathrm{D}_{2}$ & 295.0 & 49.40 \\
Initial & No Heat & 282.0 & 49.00 \\
& Treatment & & \\
Improvement & & 13.0 & \\
\hline
\end{tabular}

Table 14. Verification test results for optimal heat-treatment conditions for YS

\begin{tabular}{llcc}
\hline Conditions & Level & $\begin{array}{l}\text { YS } \\
(\mathrm{MPa})\end{array}$ & $\begin{array}{l}\text { S/N Ratio } \\
(\mathrm{dB})\end{array}$ \\
\hline Prediction & $\mathrm{A}_{2} \mathrm{~B}_{3} \mathrm{C}_{3} \mathrm{D}_{2}$ & 111.1 & 40.91 \\
Measurement & $\mathrm{A}_{2} \mathrm{~B}_{3} \mathrm{C}_{3} \mathrm{D}_{2}$ & 121.0 & 41.66 \\
& No Heat & 115 & 41.21 \\
Initial & Treatment & & \\
Improvement & & 6 & \\
\hline
\end{tabular}

Table 15. Verification test results for optimal heat-treatment conditions for $\% \mathrm{El}$

\begin{tabular}{lllc}
\hline Conditions & Level & $\begin{array}{l}\% \mathrm{El} \\
(\%)\end{array}$ & $\begin{array}{l}\text { S/N Ratio } \\
(\mathrm{dB})\end{array}$ \\
\hline Prediction & $\mathrm{A}_{2} \mathrm{~B}_{3} \mathrm{C}_{1} \mathrm{D}_{2}$ & 34.53 & 30.76 \\
Measurement & $\mathrm{A}_{2} \mathrm{~B}_{3} \mathrm{C}_{1} \mathrm{D}_{2}$ & 34.17 & 30.67 \\
Initial & No Heat & 7.27 & 17.23 \\
& Treatment & & \\
Improvement & & 26.9 & \\
\hline
\end{tabular}


(a)

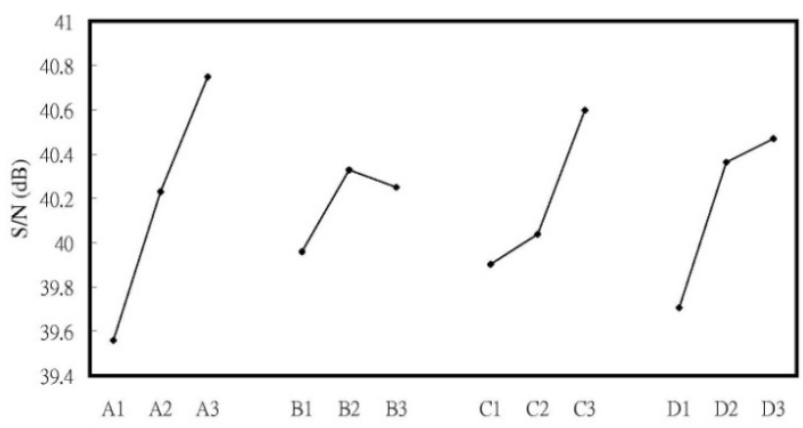

(b)

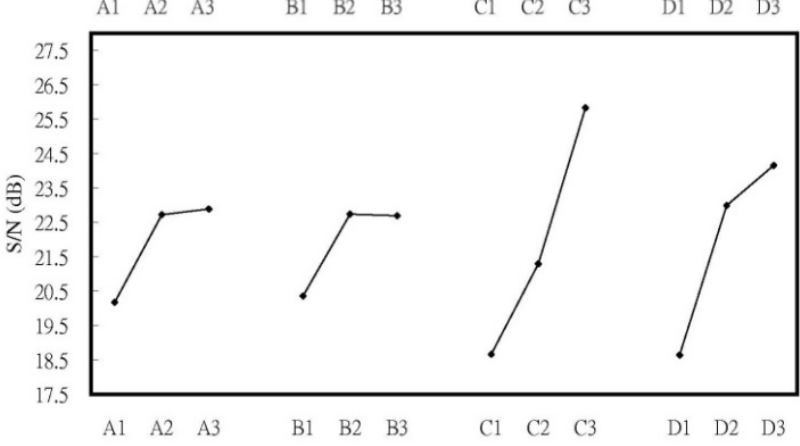

(c)

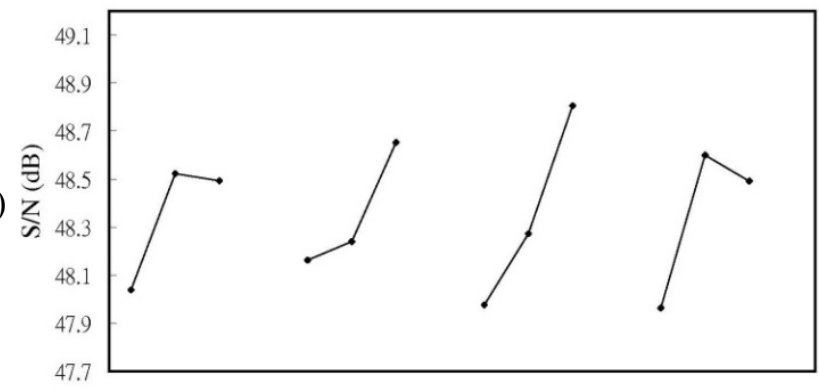

(d)

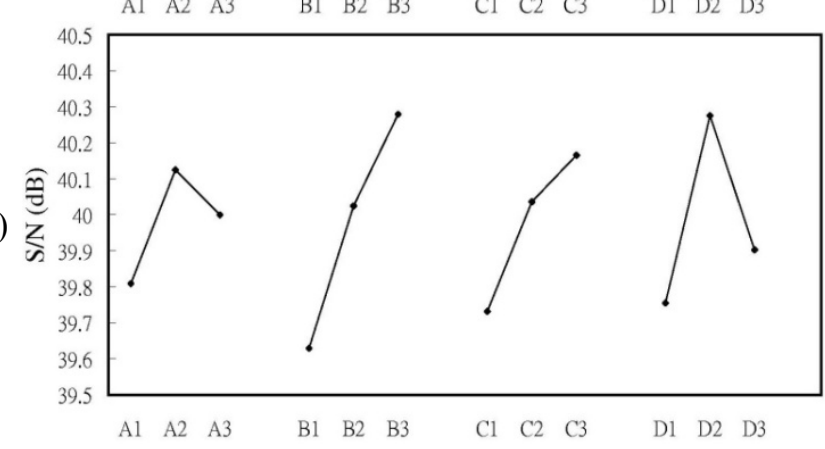

(e)

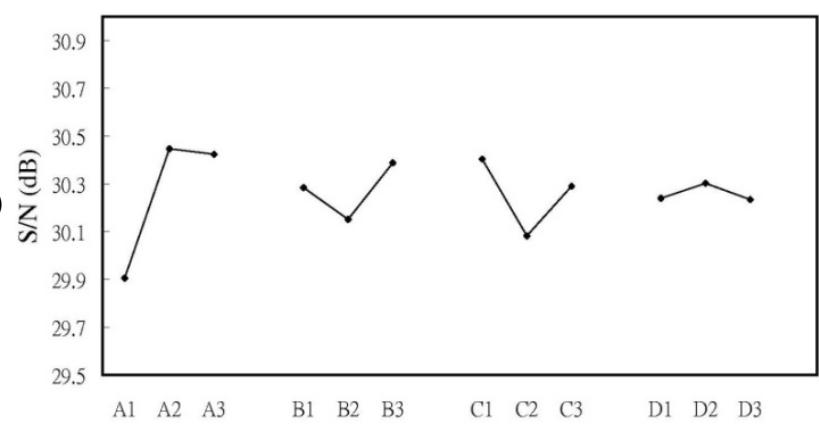

Figure 1. Signal-to-noise ratios vs heat treatment factors level for: a) microhardness; b) PBR; c) UTS; d) YS; e) $\% \mathrm{El}$ 


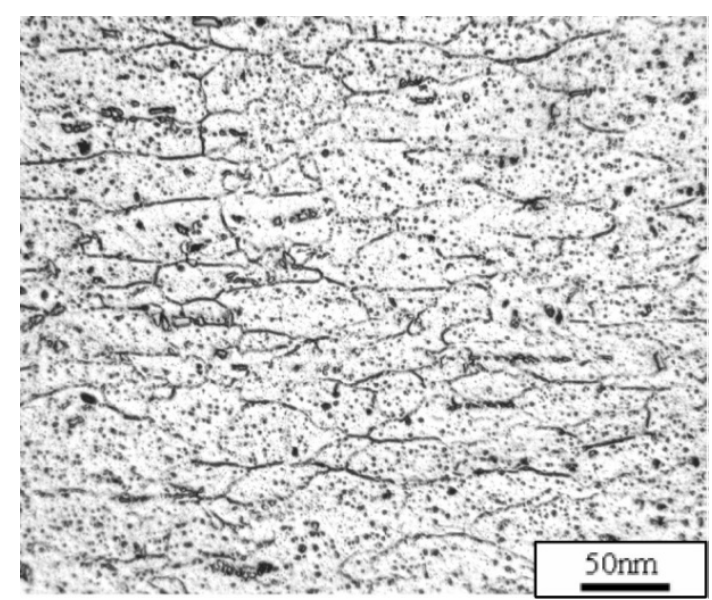

Figure 2. Microstructure of Al-Mg-Si wrought alloy before heat treatment

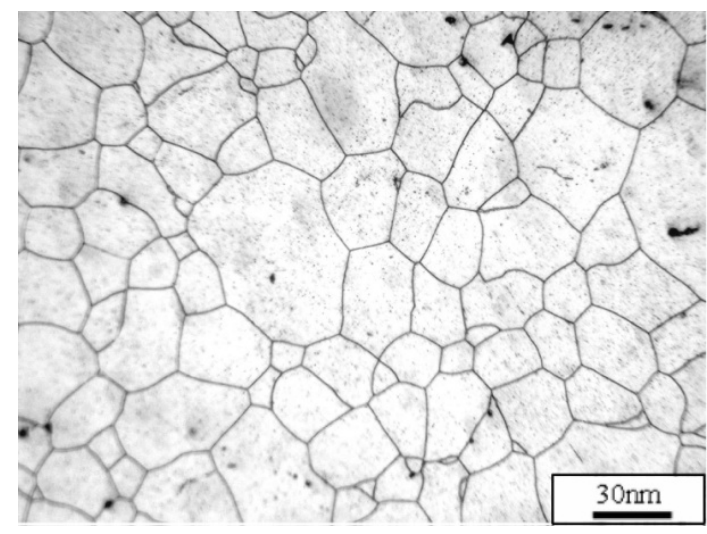

Figure 3. Microstructure of Al-Mg-Si wrought alloy after heat treatment under optimal conditions for \%El

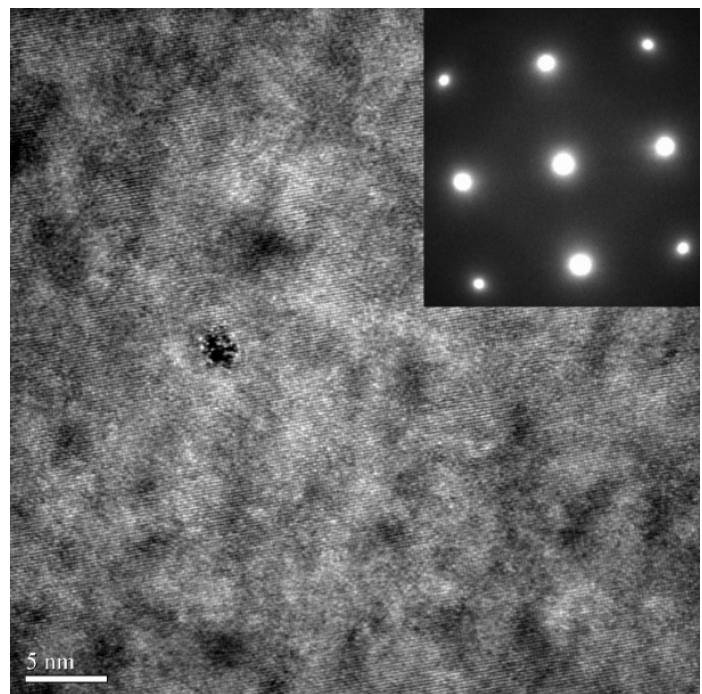

Figure 4. HR-TEM micrographs of Al-Mg-Si wrought alloy paint baked at $170^{\circ} \mathrm{C}$ for $20 \mathrm{~min}$ 